\title{
Participatory technology transfer (PTT) - an innovative approach in root (wilt) affected coconut area
}

\author{
P. Anithakumari ${ }^{1}$, S. Manoj ${ }^{1}$ and S. Arulraj ${ }^{1}$
}

\begin{abstract}
The awareness, knowledge, attitude and adoption of the root (wilt) management practices were found to be very low among the farmers of root (wilt) affected area. This disease affects the socio economic conditions due to the reduction in coconut yield. Central Plantation Crops Research Institute, Kerala (India) has developed effective integrated management technology for improving the health and yield of disease affected palms. Due to the perennial nature, prevalence of the disease in the State for more than ten decades, attitude of the farming community and other social/economic constraints, the linear model of Transfer of Technology (TOT) could not create the desirable effect. Hence an innovative Participatory Technology Transfer (PTT) approach was implemented in severely root (wilt) affected district-Alappuzha during 1999-2003. The impact analysis indicated significant improvement in awareness (14 to 32.5), knowledge (19 to 59.5), attitude (22.5 to 36.5 ) and adoption (16 to 45.5) of practices as well as the scope for scaling up the TOT model in root (wilt) affected areas. The PTT enabled participation of major stakeholders in the TOT process. The categorization of the farmers indicated significant shift to the higher level of awareness from 63.00 to $92.00 \%$, higher level of knowledge from 14.00 to 74.50 $\%$ and higher adoption level from 27.50 to $57.00 \%$ after three years of PTT approach implementation.
\end{abstract}

Key words: Participatory technology transfer (PTT) approach, integrated root (wilt) management, coconut and farmers.

*Central Plantation Crops Research Institute, Regional Station, Krishnapuram P.O., Kayamkulam, Kerala-690 533, India 


\section{Introduction}

Coconut is the base crop in the homesteads of small and marginal farmers of Kerala (India). The crop is cultivated in 9.40 lakh hectares with a total production of 5744 million nuts and productivity 5870 nuts/ha. The productivity of coconut in Kerala is low when compared to the national level (6889 nuts/ha), Tamil Nadu (9763 nuts/ha) and Andhra Pradesh (10660 nuts/ha) (Directorate of Economics \& Statistics, 2003). The constraints contributing towards the low level productivity, are the incidence of root (wilt) disease, predominance of small holdings, senile or older palms, low level of awareness, knowledge and adoption of management practices especially root (wilt) management practices as a package, absentee landlordism, pests and disease incidence and fluctuating market price (Anithakumari and Kalavathy, 2001). The transfer of technology or dissemination of knowledge among the farming community poses a challenging situation in the root (wilt) areas due to the following factors: The average holding size of the farmers is found to be very low (0.11 ha) which accommodates 21-25 coconut palms of various age levels as well as seedlings. The purpose of coconut cultivation changes from farmer to farmer and locations; but technology/practices are found to be blanket mostly.

The agricultural knowledge system management requires extra efforts of managing the technology dissemination to varied socioeconomic-personal contexts. This needs deviation from the linear model of transfer of technology (TOT) of coconut. The observability of the technology adoption in coconut is slow and low due to the physiology of the crop. Hence convincing the feasibility, practicability and other attributes of the technologies to the farmers needs patience and participatory educational approaches. The 'software' of the technology is more sensitive aspect of management than the 'hardware'. The impact in terms of yield or complete recovery from leaf rot disease may take more than two years as per the field experience and the farmers' perceptions. The stature and perennial nature of the palm, the dependence on coconut climbers for harvest/application of plant protection measures, the attitude of farmers as well as extension officials towards root (wilt) as an unmanageable disease, the homestead farming system from which the farmers perceive the total income or production rather than individual crop performance (the final perception about any technology in the system is weighed based on the final yield/economic output obtained by the farmers) and fragmentation of holdings are some of the factors influencing the TOT. The technology package recommended by Central Plantation Crops Research Institute (CPCRI) in managing the root (wilt) disease with several components includes items to be adopted regularly or prophylactically and some are need based only. The adoption period is spread throughout the year. Hence it can be noticed that the decision-making and management of the crop requires better-decentralized infrastructural support for improved adoption. The package of integrated management practices (CPCRI, 2000) include majority of the recommended coconut cultivation practices but modified to suit root (wilt) affected area, which can be grouped as nursery management practices, planting in main field and management, management of adult palms, integrated disease management practices and integrated pest management practices.

All these factors paved the way for taking up an applied research on participatory technology transfer (PTT) approach among the farmers of the root (wilt) affected area with the following objectives:

1. To evolve a participatory technology transfer (PTT) approach for improving the awareness, knowledge, attitude and adoption of the root (wilt) management practices.

2. To assess the impact of PTT in terms of awareness, knowledge, attitude and adoption of the root (wilt) management practices.

3. To study the perception of the participating farmers regarding the implementation of PTT and general constraints experienced.

\section{Materials and methods}

The farmer system as well as the coconutbased homesteads of a representative root (wilt) 
disease affected area was studied in detail for evolving the PTT methodology considering the scope, needs and requirements. The project area consisted of 25 hectares involving 208 farmers/farm families. The area had about 4500 adult coconut palms as well as more than 1000 seedlings to be managed. The study was conducted in three distinct phases during a period of three years (1999 to 2003) among 208 participant farmers i.e., before, during and after PTT approach implementation. The details of the implementation phases, methods utilized and the groups involved are furnished in Table 1 . The data were collected using a pre-tested interview schedule through personal interview. Data were further strengthened through field observations and PRA. The variables studied were measured using the following methodologies.

Awareness: Awareness was operationally defined as the feeling of being conscious of perceiving and taking into account of the recommended practices for coconut in root (wilt) affected areas by the coconut cultivators for the study. Awareness before and after PTT was measured using the methodology developed by Salunkhe (1978), which was modified to suit the present study.

Knowledge: Knowledge was operationally defined as the exposure to the technologies recommended for coconut root (wilt) affected areas and gaining proper understanding of its application. A teacher made knowledge test was prepared after discussing with experts and referring publications and used before and after PTT. The correct knowledge, incorrect knowledge and no knowledge were also analyzed from the responses obtained.

Attitude: An attitude scale was developed to measure the attitude towards root (wilt) management technologies using the method of equal appearing intervals proposed by Thurstone and Chave (1929) modified by Rajkamal and Kunzru (1998).

Adoption: Adoption was operationalized as the extent to which the respondents of the coconut root (wilt) affected area followed the recommended technologies into actual practices. Only symbolic adoption was taken after PTT.
The adoption index used by Syamkumar (1999) was modified to suit this study. The proper adoption of practices/technology, improper adoption and no adoption also were analyzed from the responses collected. Perceptions of the farmers were measured using a scoring device developed for this study in local language and the farmers were directed to indicate their responses in the 'Information Sheet' provided. The average scores were taken for the analysis. Data analysis was done using ' $t$ ' test, percentage analysis and frequency distribution. The McNemar test $\left(\mathrm{X}^{2}\right.$ value) for significance was also carried out to assess the data before and after PTT.

The methodology of PTT was evolved after several trials, analysis and involvement of farmers/farm families regarding the social science interventions. The phases, methods and groups in the PTT approach in the area of implementation are furnished in Table 1.

Table 1 presents the methods and approach of PTT of root (wilt) disease management practices. The process was continuous and the external stakeholders' efforts and involvement get reduced after the initial phases and supervision, documentation, feedback of problems/solutions/impact, farmer to farmer dissemination, scientist farmer interactions, farm women participation, taking up responsibilities of meetings etc were taken up as a natural change by the participant farmers. The crucial factor should be the inculcation of needed flexibility in deciding and implementing the PTT approach considering the human and location specificity. 
Table 1. Phases, methods and groups of participatory technology transfer (PTT) approach

\begin{tabular}{|c|c|c|}
\hline Implementation phases & $\begin{array}{l}\text { PTT methods utilized } \\
\end{array}$ & Groups involved \\
\hline $\begin{array}{l}\text { - Rapport } \\
\text { building/dialogue } \\
\text { - Creating technology } \\
\text { awareness } \\
\text { - Stakeholder analysis }\end{array}$ & $\begin{array}{l}\text { - Visit of farmers groups to research station (lab and field) } \\
\text { - Scientist-farmer interaction } \\
\text { - Distribution of extension literature in local language } \\
\text { - Utilizing mass media } \\
\text { - Bench mark survey of farmers and palms } \\
\text { - Stake holder matrix (ODA, 1995) }\end{array}$ & $\begin{array}{l}\text { Research group/first line } \\
\text { extension/farmers groups }\end{array}$ \\
\hline $\begin{array}{l}\text { Deciding the theme and } \\
\text { target group }\end{array}$ & $\begin{array}{l}\text { - Group interaction with farms by multidisciplinary team of } \\
\text { scientists } \\
\text { - Taking stock of awareness, knowledge, attitude, adoption, } \\
\text { perception and other features on root (wilt) management }\end{array}$ & $\begin{array}{l}\text { First line extension and } \\
\text { farmers groups }\end{array}$ \\
\hline $\begin{array}{l}\text { Participatory assessment } \\
\text { of existing crop and } \\
\text { farming situations }\end{array}$ & $\begin{array}{l}\text { - Informal discussions among farms and with scientists } \\
\text { - Informal group meetings } \\
\text { - Conducting PRA (transect analysis) } \\
\text { - Field and home visit }\end{array}$ & $\begin{array}{l}\text { Research/extension/farmers } \\
\text { groups }\end{array}$ \\
\hline $\begin{array}{l}\text { Identification of needs } \\
\text { and problems }\end{array}$ & $\begin{array}{l}\text { - Field visit } \\
\text { - Group interactions of scientists and farmers } \\
\text { - Observation/documentation }\end{array}$ & $\begin{array}{l}\text { Research/first line extention/ } \\
\text { extention/ farmers groups }\end{array}$ \\
\hline Technology transfer & $\begin{array}{l}\text { - Laying out result demonstrations on root (wilt) management } \\
\text { practices, explain scientific basis \& timeliness/choice of } \\
\text { - Mractices } \\
\text { - Method demonstration on skill based technologies } \\
\text { - Organizing training programmes, farmer-scientist interactions } \\
\text { - Circulars/letters } \\
\text { - Documentation }\end{array}$ & $\begin{array}{l}\text { First line extension/extension/ } \\
\text { farmer / women groups }\end{array}$ \\
\hline $\begin{array}{l}\text { Technology } \\
\text { implementation }\end{array}$ & $\begin{array}{l}\text { - Adapting or modifying techniques or fixing priorities for } \\
\text { technologies by the farmers as a continuous process (an informal } \\
\text { PTD process was initiated at this stage) } \\
\text { - Adoption of practices in discussion with and involvement of } \\
\text { participant farmers/women or whole family members } \\
\text { - Periodic group meeting/trainings }\end{array}$ & $\begin{array}{l}\text { First line extension/ farmer/ } \\
\text { women groups }\end{array}$ \\
\hline $\begin{array}{l}\text { Monitoring and follow } \\
\text { up }\end{array}$ & $\begin{array}{l}\text { - Periodical monitoring of farmers through informal interview and } \\
\text { data collection } \\
\text { - Incorporating need based changes/suggestions } \\
\text { - Circulars/letters } \\
\text { - Telephone help line/keeping activity charts/diaries with the } \\
\text { participant farmers }\end{array}$ & $\begin{array}{l}\text { First line extension/ farmer/ } \\
\text { women groups }\end{array}$ \\
\hline Participatory evaluation & $\begin{array}{l}\text { - PRA (transect walk, matrix scoring of the technologies/ practices } \\
\text { adopted, timeline of the implementation period, resource flow } \\
\text { map, technology map, seasonality of pests, diseases and } \\
\text { management of coconut homesteads) } \\
\text { - Survey of farmers and the cropped area } \\
\text { - Impression of extension officials regarding methodology and } \\
\text { technology implemented } \\
\text { - Farmers presenting the results of PRA before scientists for } \\
\text { triangulation } \\
\text { - Research-extension-farmer dialogue on the experiences/impact }\end{array}$ & $\begin{array}{l}\text { First line extension/extension/ } \\
\text { farmer /women groups }\end{array}$ \\
\hline
\end{tabular}


Table 2 indicates the broad areas in which the groups had contributed, participated and linkages nurtured for a participatory knowledge system development in the root (wilt) affected coconut areas consisting of small and marginal farmers in the community.

Table 2. The component groups and their role in the PTT

\begin{tabular}{|c|c|}
\hline $\begin{array}{l}\text { Component } \\
\text { groups }\end{array}$ & Roles \\
\hline Research group & $\begin{array}{l}\text { Developed integrated management } \\
\text { practices for root (wilt) diseased } \\
\text { coconut area, appropriately modified } \\
\text { for adoption and efficient resource } \\
\text { management }\end{array}$ \\
\hline $\begin{array}{l}\text { Firstline TOT / } \\
\text { extension } \\
\text { management } \\
\text { group }\end{array}$ & $\begin{array}{l}\text { Bringing out the TOT gaps, firstline } \\
\text { TOT efforts, designing and } \\
\text { implementing alternate approaches, } \\
\text { strengthening linkages and sustaining } \\
\text { them, monitoring and evaluation, } \\
\text { providing social science support } \\
\text { based on theories and principles }\end{array}$ \\
\hline $\begin{array}{l}\text { Field level } \\
\text { extension } \\
\text { group/informal } \\
\text { extension }\end{array}$ & $\begin{array}{l}\text { Need based supporting, involvement } \\
\text { in TOT activities, technology } \\
\text { appraisal in field level, acquire } \\
\text { knowledge /skill regarding } \\
\text { technologies besides extension } \\
\text { techniques and management skills, } \\
\text { providing feedback, and knowledge } \\
\text { management }\end{array}$ \\
\hline $\begin{array}{l}\text { Farmers' } \\
\text { groups/farm } \\
\text { women and } \\
\text { other family } \\
\text { members }\end{array}$ & $\begin{array}{l}\text { Main component of the approach was } \\
\text { to assess the technology, adopt the } \\
\text { practices, acquire knowledge and skill } \\
\text { for continued adoption. Nurturing and } \\
\text { sustaining links with research and } \\
\text { extension systems, serving as major } \\
\text { facilitators } \\
\text { transferring/disseminating tor } \\
\text { knowledge and technologies, } \\
\text { feedback on negative and positive } \\
\text { impacts perceived by them. Attaining } \\
\text { key positions in technology } \\
\text { development and dissemination; } \\
\text { whole family approach is important in } \\
\text { the case of homestead agriculture }\end{array}$ \\
\hline
\end{tabular}

\section{Results and discussion}

Impact of PTT in the awareness, knowledge, attitude and adoption in the root (wilt) affected area

The impact of the participatory technology transfers approach in the root (wilt) area in terms of awareness, knowledge, attitude and adoption regarding the integrated root (wilt) management practices with the significant level of changes before and after PTT is provided in Table 3.

Table 3. Impact of PTT

\begin{tabular}{|l|c|c|c|}
\hline \multirow{2}{*}{\multicolumn{1}{|c|}{ Variables }} & \multicolumn{2}{|c|}{ Average scores } & \multirow{2}{*}{ 't' value } \\
\cline { 2 - 3 } & $\begin{array}{c}\text { Before } \\
\text { PTT }\end{array}$ & $\begin{array}{c}\text { After } \\
\text { PTT }\end{array}$ & \\
\hline Awareness & 14.11 & 32.53 & $14.3452 * *$ \\
\hline Knowledge & 18.84 & 59.47 & $08.0527 * *$ \\
\hline Attitude & 22.56 & 36.48 & $04.3811 * *$ \\
\hline Adoption & 16.32 & 45.58 & $06.8981 * *$ \\
\hline
\end{tabular}

** Significant at 0.05 levels

The data indicate that there was impressive improvement in the awareness, knowledge, attitude and adoption of the recommended coconut root (wilt) management practices among the participant farmers of the PTT approach. The change in the awareness was high indicating the lack of required technology transfer efforts at field level. This would create the necessary grounds for the better knowledge acquisition and further utilization of the technologies. This also paved the way for erasing misconception about technologies such as incidence of boron deficiency, cause of root (wilt) disease, root (wilt) as a manageable disease and prevalent low cost technologies from research system and improving the positive attitude towards the technology package. Similarly, significant improvements were recorded with reference to attitude and adoption. The data clearly show the impact of PTT approach in empowering the farmers as good decision-makers in farming. It also indicates the success of PTT in changing the time old misconception and lack of awareness among the coconut farmers for better achievement of research systems' utility. 
Awareness level of integrated root (wilt) management practices

Awareness of recommended practices encourages farmers to seek more scientific/practical knowledge and skill so that it can be utilized for better farming.

The overall awareness level of respondents on integrated root (wilt) management practices was assessed and the findings are presented in Table 4.

Table 4. Overall awareness level of respondents

\begin{tabular}{|l|r|r|r|r|l|}
\hline \multirow{2}{*}{$\begin{array}{c}\text { Category } \\
\text { of } \\
\text { awareness }\end{array}$} & \multicolumn{2}{|c|}{ Before PTT } & \multicolumn{2}{|c|}{ After PTT } & \multirow{2}{*}{$\begin{array}{c}\mathrm{X}^{2} \\
\text { Value }\end{array}$} \\
\cline { 2 - 5 } & Number & $\%$ & Number & $\%$ & \\
\hline Low & 23 & 11.50 & 7 & 3.50 & $1.29 \mathrm{NS}$ \\
\hline Medium & 51 & 25.50 & 9 & 4.50 & $7.47 * *$ \\
\hline High & 126 & 63.00 & 184 & 92.00 & $3.90^{*}$ \\
\hline Total & 200 & 100.00 & 200 & 100.00 & \\
\hline
\end{tabular}

** Significant at 0.01 level, *Significant at 0.05 level, $\mathrm{NS}=$ Non significant

From Table 4 it can be inferred that majority of the respondents $(92.0 \%)$ had high level of awareness about integrated root (wilt) management practices after PTT. Only 3.5 percent were in the low awareness level category. The improvement of awareness from 63.00 per cent to 92.00 per cent in the case of high-level category was found to be statistically significant, and shows the impact of PTT approach.

The continuous exposure to technology recommendations like direct and indirect contact with subject experts/extension officials, on the field technology support/services, need based publicity through mass media, circulars/letters and interactive meetings would have created improved awareness.

Knowledge level on integrated root (wilt) management practices

The practice wise knowledge level was studied before and after PTT. The overall knowledge levels of respondents on integrated root (wilt) management practices were assessed and the findings are given in Table 5.

Table 5. Overall knowledge level of respondents $(n=200)$

\begin{tabular}{|l|c|c|c|c|c|}
\hline \multirow{2}{*}{$\begin{array}{c}\text { Category } \\
\text { of } \\
\text { knowledge }\end{array}$} & \multicolumn{2}{|c|}{ Before PTT } & \multicolumn{2}{c|}{ After PTT } & \multirow{2}{*}{\begin{tabular}{|}
$\mathrm{X}^{2}$ \\
Value
\end{tabular}} \\
\hline Low & 69 & 34.50 & 18 & 9.00 & $6.89^{* *}$ \\
Medium & 103 & 51.50 & 33 & 16.50 & $8.50^{* * *}$ \\
High & 28 & 14.00 & 149 & 74.50 & $17.18^{* *}$ \\
\hline Total & 200 & 100.00 & 200 & 100.00 & \\
\hline
\end{tabular}

** Significant at 0.01 level, *Significant at 0.05 level, NS= Non Significant

Table 5 indicates that the category of high knowledge level of 14.00 percent before PTT approach was increased to 74.50 percent after PTT. The improvement was found to be significant. In the PTT approach, scientist-farmer interaction, research lab visits, method demonstration and training programmers were conducted based on their needs. They paved the way to improve the knowledge level of respondents.

\section{Adoption of integrated root (wilt) management practices}

Adoption is a decision on the part of farmers to make use of an innovation as a best course of action available. The overall adoption level of respondents on integrated root (wilt) management practices was assessed and the findings are given in Table 6.

Table 6. Overall adoption level of respondents $(n=200)$

\begin{tabular}{|l|c|c|c|c|l|}
\hline \multirow{2}{*}{$\begin{array}{l}\text { Category of } \\
\text { adoption }\end{array}$} & \multicolumn{2}{|l|}{ Before PTT } & \multicolumn{2}{l|}{ After PTT } & \multirow{2}{*}{$\mathrm{X}^{2}$} \\
\cline { 2 - 5 } & Number & $\%$ & Number & $\%$ & \\
\hline Low & 83 & 41.50 & 50 & 25.00 & $1.90 \mathrm{NS}$ \\
Medium & 62 & 31.00 & 36 & 18.00 & $0.80 \mathrm{NS}$ \\
High & 55 & 27.50 & 114 & 57.00 & $2.72 *$ \\
\hline Total & & 100.00 & 200 & 100.00 & \\
\hline
\end{tabular}

** Significant at 0.01 level, *Significant at 0.05 level, NS= Non Significant

The overall adoption categories indicate that only about a quarter of the respondents (27.50\%) were in the high adoption level before PTT. But 
after PTT more than half of the respondents $(57.00 \%)$ were in the high adoption category. The improvement in the case of high level of adoption was found to be statistically significant. The before PTT distribution was supported by findings of Payal (1999), Anithakumari and Kalavathy (2001) and Vinothkumar (2002).

\section{Practice wise gain after PTT}

For improving adoption, the farmers were trained about the technologies and interactive group discussion about the technology were conducted which resulted in the desired impact (Table 7).

Table 7. Practice wise gain in awareness, knowledge and adoption after PTT $(\mathbf{n}=\mathbf{2 0 0})$

\begin{tabular}{|l|c|c|c|}
\hline \multirow{2}{*}{ Technologies } & \multicolumn{3}{|c|}{ Improvement in \% } \\
\cline { 2 - 4 } & Awareness & Knowledge & Adoption \\
\hline $\begin{array}{l}\text { Nursery management } \\
\text { practices }\end{array}$ & 26.40 & 34.23 & 35.40 \\
\hline $\begin{array}{l}\text { Planting in main field } \\
\text { and management }\end{array}$ & 18.00 & 35.00 & 32.53 \\
\hline $\begin{array}{l}\text { Management of adult } \\
\text { palms }\end{array}$ & 32.50 & 40.83 & 35.33 \\
\hline $\begin{array}{l}\text { IDM practices of } \\
\text { coconut }\end{array}$ & 70.00 & 66.79 & 50.75 \\
\hline IPM practices of coconut & 41.50 & 36.80 & 17.50 \\
\hline \multicolumn{1}{|c|}{ Mean percentage } & 37.68 & 42.73 & 34.30 \\
\hline
\end{tabular}

Table 7 indicates that the knowledge improvement was to the tune of 42.73 per cent regarding the integrated disease management practices after the PTT approach implementation for three years. The maximum improvement was recorded with reference to awareness (70.00 per cent), knowledge (66.70 per cent) and adoption (50.75 per cent) in the integrated disease management practices which includes identification of symptoms, management practices, dosage, method and time of application of fungicides etc. of root (wilt) disease, leaf rot, stem bleeding and boron deficiency in coconut. The awareness improvement in case of nursery management and planting in main field and management was found to be low (26.40 per cent and 18.00 per cent respectively) which might be due to the high awareness level already available among the farmers. Majority of the practices were traditional/indigenous and practiced over hundreds of years by the farmers except a few technologies like poly bag seedlings and lack of awareness about the prevalence and skill in identifying root (wilt) disease tolerant/resistant mother palms in the disease tract. More than 40.00 per cent improvement was found in the awareness on recommended IPM practices (41.50 per cent) and knowledge on adult palm management practices (40.83 per cent). The utility of PTT approach in improving the awareness, knowledge and adoption of recommended practices was amply evident from Table 7. The need for formulating appropriate extension methodologies or approaches after analyzing the field and farmers situations according to detailed inventory on individual practices/technologies is advocated for utilization.

\section{Overall impact of PTT in IDM}

Table 8 provides the overall level of awareness, knowledge and adoption of integrated root (wilt) disease management practices.

The impact of PTT approach was evident from the changes (Table 8). With reference to knowledge and adoption, marked reduction could be noticed in the case of incorrect knowledge (36.16 \% reduction), no knowledge (5.21\% reduction) and improper adoption (13.00\% reduction) and no adoption ( $14.00 \%$ reduction).

Table 8. Change in awareness, knowledge and adoption regarding root (wilt) management practices

\begin{tabular}{|l|c|c|c|}
\hline \multicolumn{1}{|c|}{ Variables } & $\begin{array}{c}\text { Before } \\
\text { PTT (\%) }\end{array}$ & $\begin{array}{c}\text { After PTT } \\
(\%)\end{array}$ & Change (\%) \\
\hline $\begin{array}{l}\text { Awareness } \\
\text { Aware }\end{array}$ & 63.72 & 91.03 & +27.13 \\
Not aware & 36.28 & 08.97 & +40.47 \\
\hline Knowledge & 37.94 & 78.41 & -36.16 \\
Correct & 48.76 & 12.60 & \multicolumn{3}{|c|}{} \\
Incorrect & \multicolumn{3}{|l}{} \\
\hline
\end{tabular}




\begin{tabular}{|l|l|l|l|}
\hline No knowledge & 13.30 & 08.09 & -05.21 \\
& & & \\
\hline Adoption & & & \\
Proper & 27.50 & 54.90 & +27.40 \\
Improper & 30.90 & 17.90 & -13.00 \\
Nil & 41.60 & 27.50 & -14.00 \\
\hline
\end{tabular}

Perception of the farmers regarding the implementation of the project

The perception of the farmers regarding the implementation of the project was recorded in order to improve upon and drawing lessons on the procedures. The criteria considered were the adoption of technologies, utility of training programmes, co-operation and participation of CPCRI staff, timely communication of information, plot visit by the staff, field problem solving, consideration of farmers' opinion and co-operation and participation of the farmers (Table 9).

Table 9. Perception of the farmers about the implementation of the project

\begin{tabular}{|c|c|c|c|}
\hline Items & $(3)^{*}$ & $(2)^{*}$ & $(1)^{*}$ \\
\hline Adoption of the recommendations & 65.0 & 35.0 & 0 \\
\hline Utility of the training programmes & 42.7 & 28.6 & $28.7 \#$ \\
\hline $\begin{array}{l}\text { Co operation / participation of } \\
\text { CPCRI staff }\end{array}$ & 78.5 & 21.4 & 0 \\
\hline $\begin{array}{l}\text { Timely communication of } \\
\text { information }\end{array}$ & 71.4 & 28.6 & 0 \\
\hline Plot visit of staff & 85.7 & 14.3 & 0 \\
\hline Field problem solving & 71.4 & 28.6 & 0 \\
\hline Consideration of farmers' opinion & 69.3 & 30.7 & 0 \\
\hline $\begin{array}{l}\text { Co operation/participation of the } \\
\text { farmers }\end{array}$ & 64.3 & 14.3 & 21.4 \\
\hline
\end{tabular}

Table 9 shows that $60-80$ per cent of the farmers perceived higher level of satisfaction on various factors which indicate the success of participatory programme. The farmers themselves recorded that 28.7 per cent of them could not attend the training programmes due to several personal and social constraints. They also opined that the participation of the farmers ought to be improved for better implementation of development programmes.

\section{Constraints in PTT}

The involvement of key stakeholders and technology along with the strenuous $R \& D$ of coconut gave a multifaceted outlook to the constraints involved in the PTT implementation. On the basis of the importance perceived by them, the partners elicited about 36 constraints. These constraints were categorized as extension system, farmers system, research system and situational constraints. The most important constraints expressed by more than 50 per cent of the samples as the main hurdle in PTT implementation were non-appreciated quantum of work/time devoted for the PTT, general nonwillingness to accept farmers and extension system as partners of $R \& D$, lack of specific technology recommendation for small and marginal farmers, rigidity of recommendations and policy framework, fluctuating prices of coconut, negative propaganda on coconut oil by lobbies coupled with lack of skilled workers/climbers, high input/wage costs, diminished interest of youth in farming, fragmented holdings, and large number of farmers with diversified interest to deal with by extension system.

Participatory approaches need special effort in involving the stakeholders and the researchers as partners. Moreover it is time consuming, requires multidisciplinary co-operation and sustained interest, to be inculcated in field programmes. The action or applied research under discussion had the advantages like involvement of the research scientists and staff, a sincere supportive team effort in planning and implementation and this could be replicated elsewhere also for reinforcement of the positive impact. However, there is always room for improvement, refinement or changes to achieve the expected objectives. The quality of participatory work largely depends on the interactions between the research team and rural people. Regular follow up, adaptations according to locality/culture and training of partners are other supportive activities needed. The system 
involvement would be complete only if the marketing system is also involved in the PTT process. The sustainability of the system may have to be studied after appropriate time gap and the process could be continued with modification. The vertical/ horizontal trickling effect among the farming community along with the influence made on extension and research system also are to be studied for improving the scaling up into further areas.

\section{Acknowledgement}

The authors thank the Director, CPCRI, Kasaragod; Present and former Head of regional station - for facilities, interest and involvement in this study. The help rendered by the technical staffs in data collection, field work and statistical analysis is duly acknowledged.

\section{References}

Anithakumari, P. and Kalavathy, S. 2001. Knowledge and adoption of recommended practices by coconut cultivators of root (wilt) affected area. Indian Cocon. 31(9): 14-17.

Anonymous, 2001. Report. Directorate of Statistics and Economics, Ministry of Agriculture, Government of India, New Delhi, India.

CPCRI, 2000. Annual Report. Central Plantation Crops Research Institute, Kasaragod, Kerala, India.

ODA, 1995. Guidance note on how to do stakeholder analysis of aid projects and programmes. Social Development Department, Overseas Development Administration, London, pp. 17-19.

Payalgogia, 1999. Developing a strategy for coconut production in Andaman and
Nicobar Islands. Unpublished M.Sc. (Ag.) Thesis, Tamil Nadu Agricultural University, Madurai, India.

Rajkamal, P. J. and Kunzru, O. N. 1998. A scale to measure attitude of farmers towards goat rearing. J. Extn. Edn. 4: 2177-2182.

Salunke, G.V.1978. A scale to measure small farmers' attitude towards SFDA. Indian J. Exten. Edu. 14 (1\&2): 66-69.

Syamkumar, B. Y. 1999. Extension intervention for sustaining rice production. Unpublished M.Sc. (Ag.) Thesis, Kerala Agricultural University, College of Agriculture, Vellayani, Kerala, India.

Thurstone, L. S. and Chave, E. C. 1929. Measurement of Attitude. University of Chicago Press, Chicago, USA.

Vinothkumar, 2002. Knowledge and adoption of recommended coconut farming practices in Thiruvananthapuram District. Unpublished M.Sc. (Ag.) Thesis, Annamalai University, Anamalai Nagar, Tamil Nadu, India. 